\title{
Profitability and sustainability of peri-urban vegetable production systems in Vietnam
}

\section{H,G.P. JANSEN ${ }^{1,3 *}$, D.J. MIDMORE ${ }^{1,4}$, P.T. BINH ${ }^{2}$, S. VALASAYYA ${ }^{1,5}$ and L.C. TRU ${ }^{2,6}$}

' Asian Vegetable Research and Development Center (AVRDC), P.O. Box 42, Shanhua, Tainan 741, Taiwan R.O.C.

${ }^{2}$ Department of Economics, University, of Agriculture and Forestry (UAF), Thu Duc - Ho Chi Minh City, Vietnam

3resent address: Research Program for Sustainability in Agriculture (REPOSA CATIE/UAW/MAG), Ápdo. 224, 7210 Guápiles, Costa Rica

- Present address: Department of Biology, Central Queensland University, Rockhampton QId 4702, Australia

SPresent address: International Crops Research Institute for the Semi-Arid Tropics (ICRISAT), Patancheru P.O., 502324 Andhra Pradesh, India

6 Present address: Department of Agricultural Economics, Cornell University, Ithaca, N.Y. 14853-7801, U.S.A.

* Corresponding author (fax +506-7102327, e-mail hjansen@sol.racsa.co.cr)

Received 1 November 1995; accepted 30 March 1996

\begin{abstract}
Urban populations in Vietnam are growing up to almost four times as fast as in rural areas, fueling the demand for timely supplies of fresh vegetables to cities. Much of this increased demand, particularly for the more perishable species, is satisfied through peri-urban production which has significantly increased since the change from centrally planned and collective systems to a market economy. Around Ho Chi Minh City farms are small (on average about 0.8 hectare), two-thirds which are de facto owned and with about $60 \%$ dedicated to vegetables, Most vegetable farmers also grow rice and/or groundnut, while cabbage is the most commonly grown vegetable crop. Vegetables próvide about $\$ 1000$ total revenues, or $\$ 650$ added value (returns to labor, land and management) year ${ }^{-1}$ farm $^{-1}$. Added value day ${ }^{-1}$ hectare ${ }^{-1}$ of vegetables is double or more than that for rice, providing employment for five or more times the number for rice, despite very high labor use. The negative correlation between farm size and cropping intensity suggests that labor is a factor limiting vegetable production enterprises. One of the major demands on labor is for irrigation. Major input costs relate to organic materials, chemical fertilizers and pesticides, although much variability exists between crops. Pests, and low and variable vegetable prices, were the most commonly cited constraints. The latter is subject to previously unknown market forces, while for the former some integrated pest management practices are being used. There is a clear trough in vegetable supply during August to October following the hot-wet months, and an apparent overuse of chemical fertilizers and insecticides. Lack of communal purchase of inputs and marketing limit the success of market-oriented vegetable farms.
\end{abstract}

Keywords: peri-urban, profitability, sustainability, vegetables, Vietnam 


\section{Introduction}

Given domestic vegetable production of some 4 million tons (t) year ${ }^{-1}$ (Table 1), a population of nearly 70 million (Anonymous, 1994), a very limited import capability, and assuming average post-harvest losses of some $20 \%$, current average year-

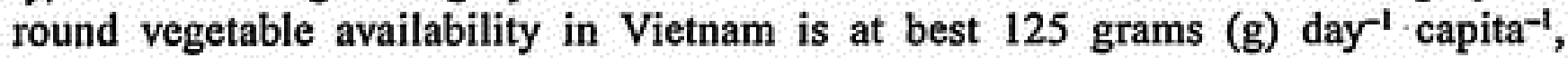
falling significantly short of the $200 \mathrm{~g}$ considered necessary to meet daily micro-nutrient requirements (Ali \& Tsou, 1996). Despite the expected decrease in population growth in Vietnam over the next two decades, growth in demand for vegetables has been projected to significantly exceed supply growth, mainly due to strong expected growth in income capita-1 (Anonymous, 1994; Jansen, 1992).

The nutritional status of the Vietnamese population has been described as extremely low, resulting in serious degradation of human capital resources (Anonymous, 1989; Xuan \& Timmer, 1990). Improving nutrition levels receives high priority in social development programs sponsored by international agencies (Anonymous, 1991). Vitamin A and other micro-nutrient deficiencies were singled out as particularly serious, pointing to the importance of increased availability of vegetables (Ali \&Tsou, 1996). Improvements in the management of the natural resources base, better crop management, identification and introduction of appropriate production technologies, and better handling and marketing of the products all could contribute to achieving the goal of increased vegetable availability. As in other Southeast Asian countries (Hayami et al., 1990), diversification is of paramount importance in Vietnamese agriculture, particularly in view of the relatively low returns carned in the predominant cultivation of rice. Increased production of vegetables has to be achieved mainly through yield increases, in view of the limited opportunity for cxpanding land area (Barker, 1993).

Future demand pressure for vegetables can be expected to be especially high in and around urban areas, mainly because people in urban areas depend to a much larger extent on market supplies for their food consumption than rural people, and urban regions usually have higher incomes and exhibit faster income growth than rural areas. While nearly every Vietnamese family in the rural areas maintains a little garden for subsistence, this is not at all the case in urban areas (Xuan \& Timmer, 1990). Also, the urban population in Vietnam has grown at an annual rate of nearly $3.5 \%$ during the past decade, compared to an overall population growth of about $2 \%$

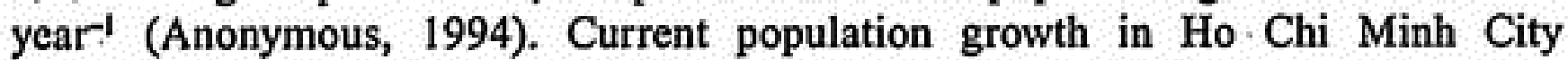
(HCMC) is estimated to exceed 7\% year-1 (Anonymous, 1995a). Apart from evidence of continuing underinvestment in agricultural research (Barker, 1993), national, bilateral and 'multilateral research efforts in Asia have largely been focusing on overcoming the deficiency in the supply of main staple foods, and very little research efforts have been made for vegetables.

HCMC, the largest city in Vietnam with well over four million inhabitants (Table 2), depends to a large extent on small-scale vegetable producers located in the socalled 'Green Belt' around the city (up to about $35 \mathrm{~km}$ from the city center) for its daily supply of vegetables. To assess the adequacy and sustainability of vegetable supplies to the rapidly growing urban population of HCMC, there exists a clear need 
to quantify production and prices of different vegetables on a calender year basis by studying input-output relations and production constraints, as well as by analyzing profitability of vegetable production.

This paper reports on the main results of a vegetable research project jointly executed in Vietnam by a national research institute (the University of Agriculture and Forestry) and an international agricultural research institute (the Asian Vegetable Research and Development Center). Main goal of the project was to identify the influence of the policy changes on the income and cropping systems of peri-urban vegetable farmers around HCMC, as well as on the constraints and opportunities for improvements in vegetable production and marketing.

To achieve this goal, the next section considers the development of agricultural policies in Vietnam in a historical perspective. Subsequently, data from an extensive field survey are used to analyze vegetable growing practices in the 'Green Belt' in terms of farming systems, cultivation methods and input-output coefficients. After describing the methodology and some basic sample characteristics, the profitability of crops other than vegetables is investigated. Peri-urban vegetable production systems in the 'Green Belt' are described in detail in the subsequent section, including an estimate of production costs of vegetables which allows an assessment of relative profitability of vegetables. Inflation in Vietnam is now under control (less than $10 \%$ annum ${ }^{-1}$ during 1992 and 1993) and the Dong has been rather stable in 1993 at around 10,800 to the US dollar (\$). Therefore, the financial returns generated by the survey results should remain valid for a considerable period of time before becoming obsolete. The analysis also contains a comparison of the total quantities of vegetables currently reaching the HCMC market with supplies needed to meet present and future nutritional requirements; an assessment of production constraints; and an analysis of the sustainability of current production practices. The final section offers some suggestions for the development of vegetable production and delivery systems that closely link farm production capacity to market requirements.

\section{The evolution of agricultural policies in Vietnam}

Government agricultural policies, particularly those related to (de-)collectivization, have had a profound influence on the organization and performance of the agricultural sector in Vietnam. Until 1975, the former South Vietnam was a private enterprise economy, unlike the former North Vietnam where agricultural production had been organized around cooperatives since 1961. After the reunification in 1975, and until 1981, the government conducted an active collectivization policy in the southcrn provinces also. However, collectivization in the southern provinces was pursued to a lesser degree than in the north. Cooperatives can be divided into production cooperatives and input supply/marketing cooperatives, and agricultural production in southern Vietnam was mostly organized around input supply/marketing cooperative farms (including a number of vegetable input supply/marketing cooperatives around HCMC), with production cooperative farms accounting for less than $10 \%$ of all farms. In input supply/marketing cooperative farms, production activities were 
largely carried out on a family farm basis, and collective effort was made only for obtaining inputs' and for marketing outputs. In the production cooperative farms in the northern provinces, however, farm households handed their property over to the cooperative. In the cooperatives; all farm work was carried out with communally owned equipment, and each household received remuneration based exclusively on the recorded labor hours of its family members. The considerable differences in historical agricultural productivity between northern and southern Vietnam can largely be explained by differences in organization of production, as well as by a series of land reform measures implemented in South Vietnam between 1956 and 1974 (Pingali \& Xuan, 1992).

The cooperative system had two serious drawbacks. First, since the legal title to the land belonged to the cooperatives rather than to individual farmers, the cooperatives' management made all production and marketing decisions. However, management decisions were often ill-timed and/or inappropriate vis-a-vis the actual market situation, resulting in structural excess supply or demand and high post-harvest losses. Second, the household remuneration system led to overstaffed management and a lack of attention to both quality and quantity of the produce.

Decollectivization policies were pursued since 1981 when a contract production system was introduced in which farmers entered into a contract with the cooperative to produce a certain level of output of a specified crop on land allocated to individual households. Even though any additional output could be kept for home consumption and/or sale to private traders; crop choice decisions were still not guided by market forces. Moreover, the lack of long-term security.of land tenure remained as the land could still be reallocated at the will of the management of the cooperative. Combined with the fact that farmers were allowed to rent land only by the season, incentives for productivity-enhancing investments were lacking. Nevertheless, the decollectivization policies succeeded in stemming the rapid decline in productivity. For example, vegetable yields, while decreasing at an annual rate of $3.3 \%$ during 1976-80, increased marginally $\left(0.4 \%\right.$ year $\left.^{-1}\right)$ during $1981-85$ (Xuan \& Timmer, 1990; Table 1).

As a result of the increasing awareness among Vietnam's policy makers regarding the crucial role that the agricultural sector plays in generating employment, income, domestic savings, foreign exchange, and food security (Barker, 1993), additional policy reforms were initiated in the second half of the 1980's. The new reforms focused on increased security of land tenure; privatization of output markets; decentralization of input supplies; and individual decision making for household resource allocation as well as for crop choice and management. Renewable land leases of fifteen years are now common, and bequests within the family are allowed. Thus, what used to be a contract system of production moved further towards a private production system. Farmers are no longer required to sell part of their production to the government. Instead, farmers must pay a certain amount of taxes and other commissions to the cooperatives, with the exact amount based on the assessed value of their land. Land taxes are based on the 'normal' output of the land which, in turn, is considered proportional to the value of the land. Actual land tax ranges from the equivalent of $900 \mathrm{~kg}$ of rice (currently valued at $\$ 0.10 \mathrm{~kg}^{-1}$ ) ha- for the best quality land, to 
Table 1. Area, production and yields of vegetables in Vietnam.

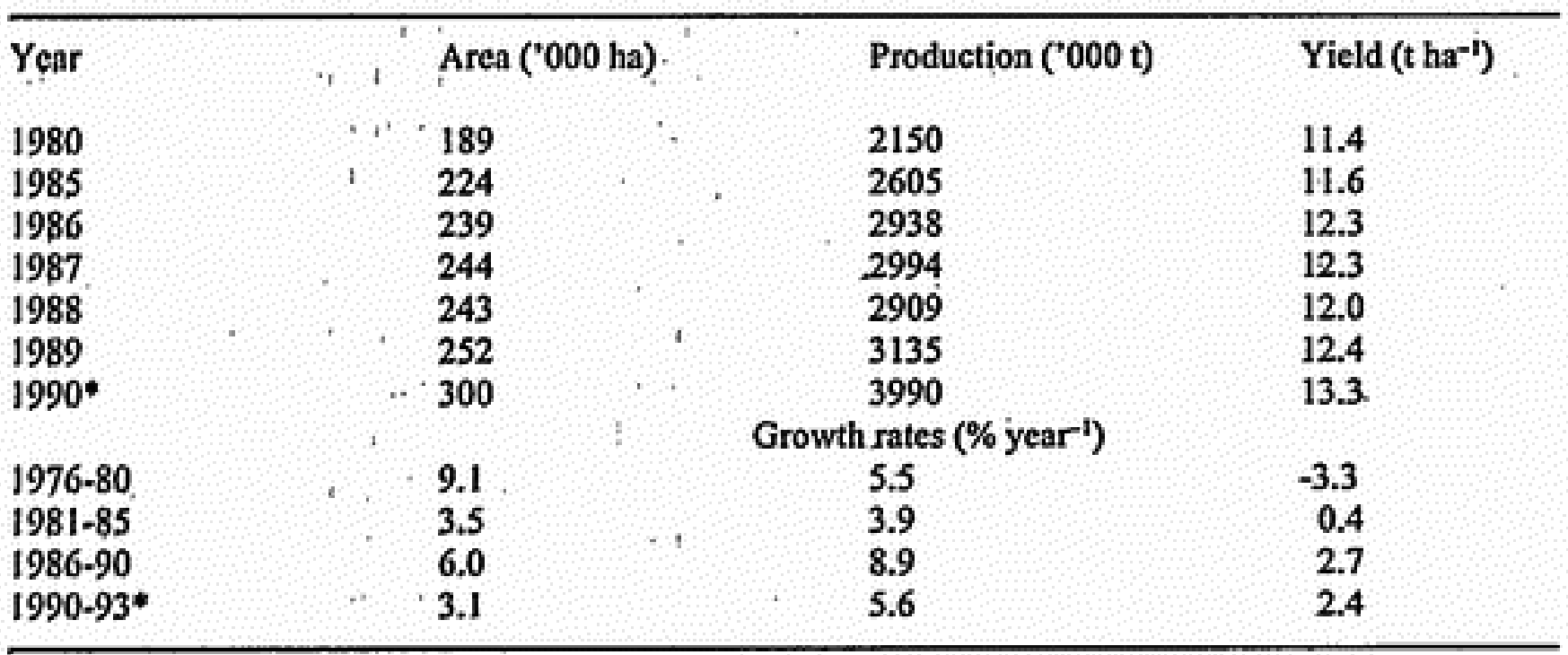

* Projected figures.

Sources: unpublished data from Ministry of Agriculture; Xuan \& Timmer (1990).

only $50 \mathrm{~kg}$ of rice equivalent for the lowest land quality. Land taxes based on the value of the land increased productivity growth by stimulating shifts from less-intensive to more-intensive cropping systems, including vegetables (Bottema et al., 1991; Hayami et al., 1990; Table 1). The government is currently undertaking a major revision of the land laws, which basically proposes the introduction of private land property rights (including making household Jand use rights transferable through the right of selling and leasing of land), even though formal state ownership is likely to be maintained. In addition, a nationwide cadastral survey has been initiated on which the government has begun to issue so-called Land Use Right :Certificates (Hayami, 1993).

Increasingly market-oriented government policies; as well-as expectations regarding upcoming revisions of the land laws, are. widely believed to have a significant impact on the performance of the agricultural sector. However, certain constraints to further productivity. increases remain: First, there are frequent shortages of essential inputs caused by shortages of foreign exchange (most modern agricultural production inputs are imported); poor development of rural credit-facilities; and insufficient market information and underdeveloped marketing skills among farmers. Second, inadequate infrastructural facilities lead to high marketing costs (Barker, 1993; Timmer, 1992): However, infrastructure quality (mainly transportation and communication systems) is significantly. better in the south than in the north of the country, and is better in urban than in rural areas. Third, farmers have to learn how to deal with seasonal gluts and shortages in the markets, with corresponding price fluctuations, the more since the quantities that the government is.willing to buy.are now more limited (especially of perishable products such as vegetables) because of the abolishment of subsidized food sales to government employees and to the army. Fourth, it is worth remembering that, even though farm production ddecisions are made with greatest efficiency, by individual farm households, cooperative-based systems offer economies of scale in input and output marketing, in credit supply, and in 
technology transfer (the intensive vegetable growing areas in Taiwan are excellent examples of organizational structures where these scale economies are highly exploited). Farmers try to partially offset high fluctuations in vegetable prices by cultivating many different species, restricting the scope for achieving scale economies, although reducing concentrations of labor requirements (Wiens, 1981); especially if compared to the pre-reform period when farmers used to cultivate only one or two kinds of vegetables at any one time. Lastly, nowadays land prices near cities are increasing rapidly because of increased pressure on the land as a result of the rapid expansion of urban areas. Consequently, the amount of peri-urban land on which vegctables can be profitably produced decreases which may have an adverse impact on vegetable supplies to urban areas. On the other hand, despite this process of marginalization of vegetable production areas from cities, improvements in transport and infrastructure may, in the long run, increase the potential vegetable production area.

\section{Survey procedure and data}

\section{Sampling methodology}

A stratified random sample consisting of 98 farmers in the four major vegetable districts around HCMC was interviewed. Samples of individual farmers were taken at random in six villages. The sample can therefore not be considered as statistically representative for peri-urban vegetable cultivation in Vietnam. It would be very difficult to estimate representativeness anyway, because of the scarcity of district and village level secondary data. On the other hand, one can expect to find similar patterns of intensive, year-round cultivation of vegetables around other major urban conglomerates in coastal Vietnam, below $20^{\circ} \mathrm{N}$. The survey was the first of its kind in Vietnam and as such had a training purpose as well. The survey data refer to the 1992 calendar year.

\section{Study area}

The districts selected included $\mathrm{Cu}$ Chi, Hoc Mon, Binh Chanh, and Go Vap, located at respectively $35,20,15$ and $8 \mathrm{~km}$ from the HCMC center. For administrative purposes, Go Vap is considered as part of HCMC center (Table 2). Historically, the area under vegetables adjacent to HCMC expanded from 1976 to 1985 due to the government push for self-sufficiency (Table 3): This was matched by a reduction in vegetable area (from 4,500 hectare (ha) in 1976 to 1,600 ha in 1985) in the Da Lat region which traditionally supplied HCMC with vegetables (Khiem \& Tien, 1996). Since reaching a peak in 1985, vegetable production area in HCMC declined as freemarket production in Da Lat picked up again. Peri-urban vegetable production tends to be quite intensive, as evidenced by vegetable yields in the survey districts which considerably exceed the national average.

Over $90 \%$ of the sample farms has flat fields, mostly with sandy-type, hydromorphic soils of light grey color and low inherent fertility (Raunet, 1994). Climatically, 
Table 2. Area and population of HCMC (1992).

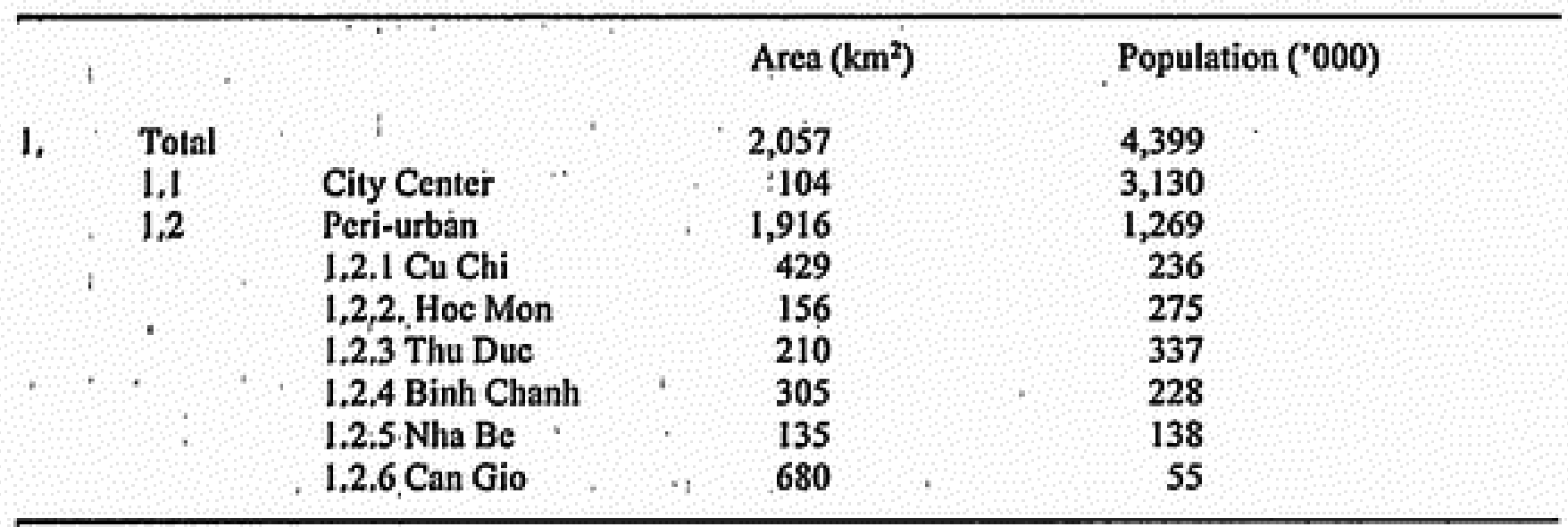

Source; unpublished data from Ministry of Agriculture.

Table 3, Vegetable area ('000 ha), production (' $000 \mathrm{t})$ and yield $\left(\mathrm{t} \mathrm{ha}^{-1}\right)$ in survey districts.

\begin{tabular}{|c|c|c|c|c|c|c|c|c|c|c|c|c|}
\hline \multirow{2}{*}{ Yenr } & \multicolumn{3}{|c|}{$\mathrm{Cu} C h i$} & \multicolumn{3}{|c|}{ Hoc Mon } & \multicolumn{3}{|c|}{ Binh Chanh } & \multicolumn{3}{|c|}{ Go Vap } \\
\hline & Area & Prod & Yicld & Area & Prod & Yield & Area & Prod & Yield & Area & Prod & Yield \\
\hline 1976 & 1,6 & 21.7 & 13,6 & 2.7 & 42.6 & 15.8 & 1.3 & 19.8 & 15.4 & 1.4 & 20.5 & 15.0 \\
\hline 1985 & 3,2 & 50.6 & 15.6 & 4.6 & 73.7, & 16.0 & 2.2 & 48.2 & 21.9 & 2.3 & 40.2 & 17.5 \\
\hline 19881 & 2,7 & 23.3 & 17.6 & 4.1 & 38.8 & 16.7 & 2.2 & 23.8 & 21.1 & 1.9 & 15.5 & 16.1 \\
\hline $1989^{\prime}$ & 2,7 & 22.2 & 17.5 & 3.9 & 40.5 & 16.9 & 3.1 & 38.9 & 20.1 & 1.9 & 16.7 & 16.5 \\
\hline $1990^{\prime}$ & 2.8 & 22,5 & 17.3 & 3.6 & 29.9 & 16.6 & 2.5 & 27.3 & 19.5 & 1.9 & 15.6 & 16.4 \\
\hline 19911 & 2,4 & 20.5 & 18.1 & 3.4 & 35.4 , & 18.4 & 2.8 & 41.3 & 23.6 & 1.6 & 14.0 & 17.2 \\
\hline $1992^{\prime}$ & 2,0 & 14.9 & 16.8 & 3.4 & $30.1^{\circ}$ & 17.6 & 1.6 & 21.1 & 23.6 & 1.7 & 16.8 & 17.7 \\
\hline 100 & 2,6 & 18.6 & 17.9 & 3.4 & 36.3 & 19.4 & 2.8 & 31.0 & 24.2 & 1.6 & 17.7 & 22.4 \\
\hline
\end{tabular}

1 Production relates only to winter-spring crops.

Source: unpublished data from Ministry of Agriculture.

HCMC experiences distinct wet (summer) and dry (winter) seasons (May-November and December-April; respectively) with annual precipitation of approximately 2,000 $\mathrm{mm}$. Monthly minimum air temperature rarely falls below $21^{\circ} \mathrm{C}$ during the dry winter season and rises in early summer to $25^{\circ} \mathrm{C}$ as do monthly maximum temperatures (to $35^{\circ} \mathrm{C}$ ). The dry winter season, with less cloud cover and lower humidity, is more suitable for temperate-type crops than is the summer, provided irrigation is available.

Farm sizes, land ownership and farming systems

Farm sizes (defined as the sum of owned' land area and rented-in area) are small, with an average of just under 0.8 ha. The majority of the cultivated area receives irri-

I Pormally all land in Vietnam is owned by the state. However, as explained earlier, the reforms of the past few years resulted in de facto ownership of the land by farmers, even though a system of full private land property rights is still under discussion. 
gation, mostly from tube wells. Vegetables are typically grown in tight sequences resulting in several crops year ${ }^{-1}$ from the same plot, making a precise estimation of the percentage of the farm area devoted to vegetables difficult. However, in terms of net cultivated area (i.e., not accounting for multiple cropping) sample farmers devote an average of $60 \%$ of their area to vegetables (Jansen et al., 1995). The relationship between crop intensity (i.e., the ratio on an annual basis of cultivated and arable area) and arable land area per farm indicates that smaller farms are cultivated more intensively $\left(y=1.57 x^{-0.46}, R^{2}=0.41\right)$. Even in highly intensive peri-urban systems, most farmers grow vegetables as part of a rice-based system; only 15 farmers grew no other crop at all, cultivating vegetables year-round. Besides rice, other important nonvegetable crops include groundnut, tobacco, and flowers (i.e., chrysanthemum and lily).

\section{Profitability of nonvegetable crops}

Net income $\mathrm{ha}^{-1}$ year-1 was calculated as the difference between total revenues (defined as total annual production $\mathrm{ha}^{-1}$ multiplied by farmgate price, i.e., accounting for the posibility of multiple crops from the same area within one year) and total cash costs incurred for seed, fertilizer (both organic and chemical), pesticides, irrigation, hired labor, and any other costs but excluding costs not specific to vegetable crops (e.g., land taxes) since these could not easily be apportioned on a crop basis. Net income defined this way is to be interpreted as returns ha $\mathrm{hear}^{-1}$ to family labor, land and management. Added value $\mathrm{ha}^{-1}$ (i.e., returns to the production factors labor, land and management) were calculated by excluding hired labor costs from the total costs calculation.

Average yearly net income earned from rice growing is low at well below $\$ 100$ $\mathrm{ha}^{-1}$, partly due to low yields averaging about $3 \mathrm{tha}^{-1} \mathrm{crop}^{-1}$. Low returns in rice cultivation can partially be explained by the opening of trade borders which makes farmers' returns dependent on rice export prices (Xuan \& Timmer, 1990). However, farm-gate prices of rice in Vietnam are very low at about $\$ 0.10 \mathrm{~kg}^{-1}$ (equivalent to about $40 \%$ of the world market price prevailing in 1992), reflecting the still significant role of the state in controlling trade in agricultural inputs and outputs and indicative of high marketing margins which result from the poor state of infrastructure.

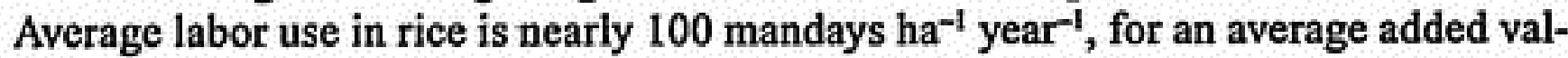
$\mathrm{ue}^{2}$ of $\$ 2.50$ day $^{-1} \mathrm{ha}^{-1}$. Average net income from groundnut at nearly $\$ 300 \mathrm{ha}^{-1}$ year $^{-1}$ is considerably higher than for rice, mainly due to higher revenues because of higher prices (Jansen et al., 1995). As a result, added value in groundnut cultivation is nearly double than that for rice, despite the fairly similar amounts of labor used. Because of the high labor requirements of tobacco (close to 700 mandays ha year $^{-1}$ on average), a relatively high net income of nearly $\$ 600 \mathrm{ha}^{-1}$ year ${ }^{-1}$ and high total

${ }^{2}$ Since family use of home-produced rice is likely on average to amount to about one half of total production, data on added value earned in rice cultivation has limited relevance since food security considerations override such data. 
added value do not translate in equivalently high added value manday ${ }^{-1}$ which is comparable to that earned in rice (Jansen et al., 1995). However, where few alternative employment opportunities exist, tobacco cultivation may be more attractive than rice growing in view of significantly higher total added value. Profitability of chrysanthemum seems much more variable than of lily, mainly caused by large differences in yield (Jansen et al., 1995). Both average net income and total added value, at respectively $\$ 1,750$ and $2,475 \mathrm{ha}^{-1}$ year-1, substantially exceed those to nonflower crops. However, flower cultivation is very labor intensive, resulting in relatively lower added values manday ${ }^{-1}$ of about $\$ 4.40$ and 3.00 for chrysanthemum and lily, respectively.

\section{Peri-urban vegetable production systems in Vietnam}

\section{Volumes of vegetable production}

Most sample farmers grew between 1 and 8 different vegetable species, with the majority of farmers growing 2 or 3 different species (Jansen et al., 1995). The total of 26 different species grown were grouped into seven categories, i.e., leafy vegetables; heading cole crops; leguminous vegetables; fruit vegetables; cucurbits; root vegetables; and aromatic yegetables. Leafy vegetables is the most widely grown category of vegetables ( $71 \%$ of all farmers) followed by cole crops ( $62 \%$ of all farmers). At the individual species level, however, English cabbage, common bean, cauliflower, and tomato were the most commonly grown vegetable crops, each grown by at least $20 \%$ of all sample farmers.

Most species yield well above $10 \mathrm{tha}^{-1} \mathrm{crop}^{-1}$ on average (Table 4). Average yearly total vegetable production is just under $30 \mathrm{t} \mathrm{ha}^{-1}$ or $12.5 \mathrm{t} \mathrm{farm}^{-1}$ (worth about $\$ 1,000$ at average prices), equivalent to an average daily vegetable production of 34 $\mathrm{kg} \mathrm{farm}{ }^{-1}$ or $80 \mathrm{~kg} \mathrm{ha}^{-1}$. Farmers growing year-round vegetables generally achieve higher yields than farmers who grow non-vegetable crops as well (Jansen et al., 1995).

Analysis of price fluctuation (price at harvest) between months reveals some variability but not as much as might have been expected if the supply of vegetables to HCMC was solely from the sample area (Jansen et al., 1995). For example, cooler scason cabbage prices are relatively stable (with the exception of October), tomato price drops in February, March and June and is low in October, and warm season cucumber and bottle gourd prices fall in the summer months. Prices for other species are all relatively insensitive to harvesting period, in spite of the strong trend towards lower total production during the summer months.

\section{Use of inputs}

Organic materials, used by virtually all farmers on all their vegetable crops, were grouped into animal waste (including cattle, pig and chicken manure), compost (an cuphemism for city waste - partially composted garbage but not sewage), coconut or 


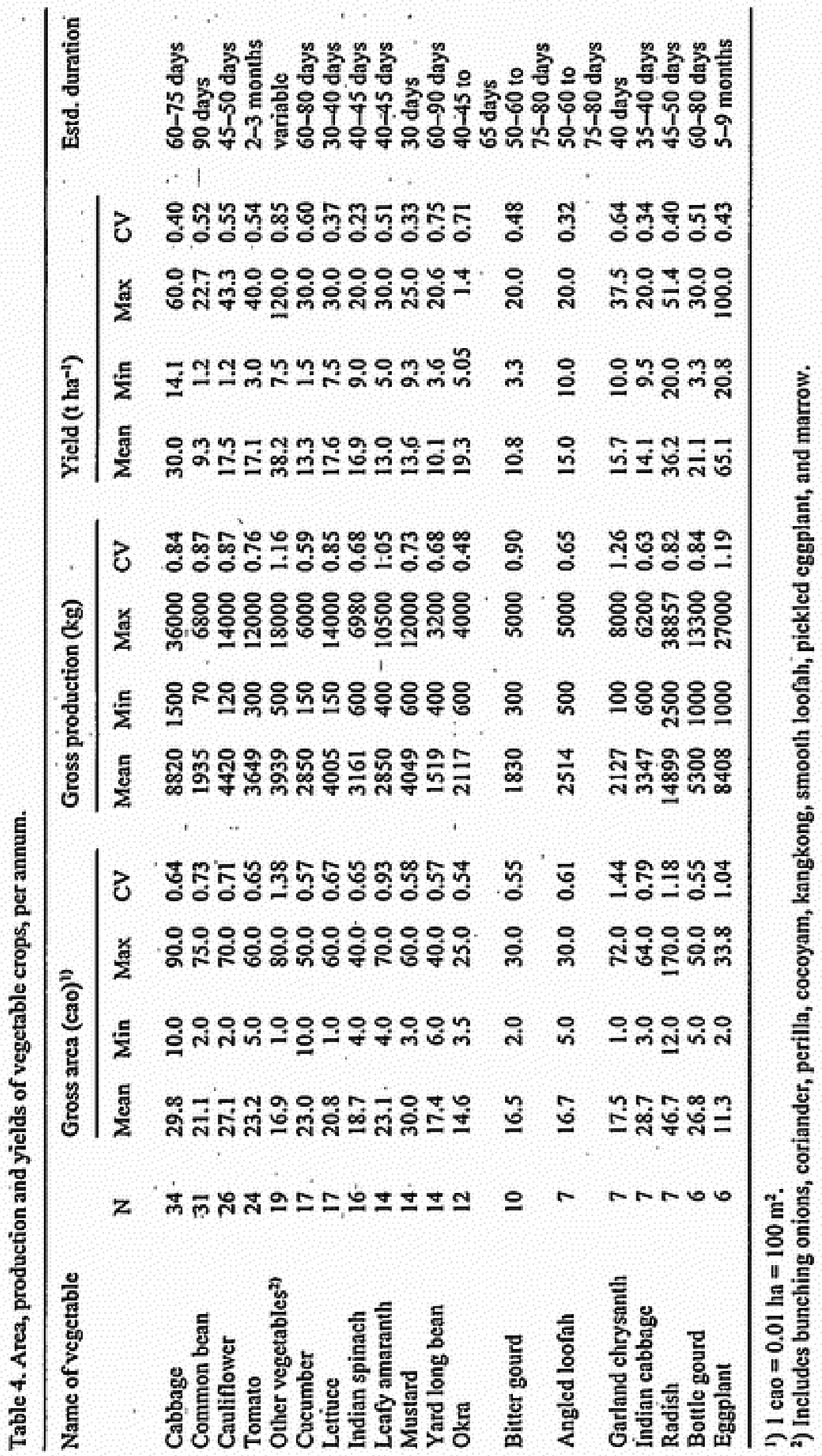


rubber cellulose, and wood dust. Animal waste and compost account for most of the organic material applied in weight terms. Average total quantities applied are highest on cucurbits, fruit vegetables, and cole crops, typically at leaist $50 \mathrm{t} \mathrm{ha}^{-1} \mathrm{crop}^{-1}$. Compared to cucurbits, fruit vegetables and cole crops, significantly lower quantitics of organic material (between 10 and $20 \mathrm{t} \mathrm{ha}^{-1} \mathrm{crop}^{-1}$ on average) are used on most leafy vegetables: In a comparison between sole vegetable farmers and those also cropping with other commodities, the former use up to twice as much organic inputs crop-1 (Jansen et al., 1995).

Use of chemical fertilizer (mostly urea) is generally high and at times seems excessive. For example, in terms of elemental nutrients, nearly $0.8 \mathrm{t} \mathrm{ha}^{-1} \mathrm{crop}^{-1}$ of NPK is applied to eggplant. Other cucurbits as well as cole crops receive applications of clemental nutrients (particularly nitrogen) in the neighborhood of $400 \mathrm{~kg} \mathrm{ha}^{-1} \mathrm{crop}^{-1}$. An analysis of the macronutrient quantities removed in harvested produce in relation to applied nutrients (both organic and inorganic forms) highlights the over-application of nutrients, particularly by year-round vegetable growers (Jansen et al., 1995). Quite evidently for some crops (e.g., tomato, lettuce and other leafy vegetables, and the gourds) farmers were aware of the contribution of organic sources to $\mathrm{P}$ and $\mathrm{K}$, but not so for $\mathrm{N}$. When applications of organic sources, of N, P, and $\mathrm{K}$ to individual crops were regressed to rates of inorganic sources, there was no overall indication that farmers compensate the use of one source with the rate of the other source (Jansen et al., 1995). Some variation across districts in the use of organic nutrients may reflect farmer choice, or that imposed by reduced availability more distant from the city center.

Pesticide use is largely limited to insecticides. Their use is highest on cole crops (average undiluted quantities sprayed exceed $301 \mathrm{ha}^{-1} \mathrm{crop}^{-1}$, with some farmers applying additional insecticides in powder form as well), followed by fruit vegetables (between 18 and $251 \mathrm{ha}^{-1} \mathrm{crop}^{-1}$ ). Quantities on cole crops are double those applied in a highland production context (Midmore et al., 1996). Leafy vegetables receive relatively little insecticides. Quantities of insecticides sprayed on fruit vegetables avcrage about $80 \%$ of quantities applied to cole crops. Cucurbits receive more insecticide than leafy vegetables but significantly less than cole crops or fruit vegetables. On the average, about $70 \%$ of the total quantities insecticides used consists of organophosphates. Bio-insecticides are used by very few farmers and limited to cole crops. Farmers cultivating only vegetables do not have a markedly different pesticide usage on a per vegetable crop basis from those cultivating other crops in addition to vegetables. Information on pesticides is mainly obtained from other farmers, radio and tclevision advertisements, and from shopkeepers, with extension services playing a negligible role in this respect. On the other hand, it should be recognized that a formal extension service came into existence only one year before the survey.

Regarding seed, despite the apparent isolation of Vietnam from the world agricultural market, the dependence on foreign sources of seed for some vegetable species is relatively high, particularly for cole crops (virtually $100 \%$ ), garland chrysanth and radish. For the remaining species, local land races or varieties predominate. Average seed costs reflect these different market sources: the cole crops, garland chrysanth and radish all have relatively high unit seed costs (Jansen et al., 1995). 


\section{Costs and returns of peri-urban vegetable production}

Costs and returns of vegetable cultivation were calculated at two levels. First, net income ha-1 year'- defined as before for nonvegetable crops, was calculated for each individual vegetable species (i.e., totals for the year for all crops of each species grown during the year). Net income calculated in this way can be interpreted as returns to family labor, land and management, plus money left over to pay for vegctable-related input costs which cannot be. attributed to individual species. such as marketing costs and miscellaneous costs. Also, added value was calculated as described before.

Second, total net income farm ${ }^{-1}$ year-1 was calculated by initially taking the sum (over vegetable species) of net incomes ha $^{-1}$ year-1, multiplied by the actual area for each individual species, minus the sum of marketing and miscellaneous costs, minus the (mostly fixed) cost items which are non-crop specific. The latter include land taxes, annualized costs of irrigation, loans, and equipment (i.e., tractor, hand tiller, spraying equipment etc.). To this were added the net incomes obtained from nonvegetable crops. Total net income farm ${ }^{-1}$ year $^{-1}$ calculated in this way can be interpreted as net profits, or returns to family labor and management.

\section{Net returns per'hectare per species}

Eggplant, the longest duration crop, has the highest input costs as well, followed by cole crops, fruit vegetables and cucurbits (Table 5). In cole crops, relatively large sums are spent on chemical fertilizers and insecticides, while manure accounts for the largest part of non-labor production costs in cucurbits. Nonlabor costs for leafy vegetables are considerably lower than for most other vegetable species, with organic materials responsible for most of these costs, and with relatively little money spent on chemicals. Most vegetable crops require between 2,000 and 5,000 manhours ha-1 $\mathrm{crop}^{-1}$, i.e., about 2.5 to 6 times higher than the amount of labor employed in rice cultivation. With the exceptions of okra, angled loofah, and common bean which are the most summer-tolerant (and therefore rainfed) crops grown, irrigation (by hand) comprises the single most time-consuming field operation within each crop (Jansen et'al., 1995).

Net incomes year-1 at average prices vary between $\$ 500$. and $1,000 \mathrm{ha}^{-1}$ for most vegetable species with the exceptions of garland chrysanth, eggplant and the heterogencous category: 'other vegetables' which yield very high incomes; cole crops, tomato, and lettuce (annual net incomes of around $\$ 1,500 \mathrm{ha}^{-1}$ ); and angled loofah which seems hardly profitable. Separate analyses for year-round vegetable farmers revealed that crops for which sole vegetable producers assigned greater inputs resulted in greater gross revenues, net incomes, and income manday ${ }^{-1}$ (Jansen et al., 1995).

For nearly all vegetables, added value manday ${ }^{-1}$ exceeds the average wage rate for hired labor in agriculture two to five times, even at the lowest prices received by farmers (Table 5). Across most species, significantly higher returns were achieved with higher levels of inputs. Moreover, comparison of farms which include rice in 


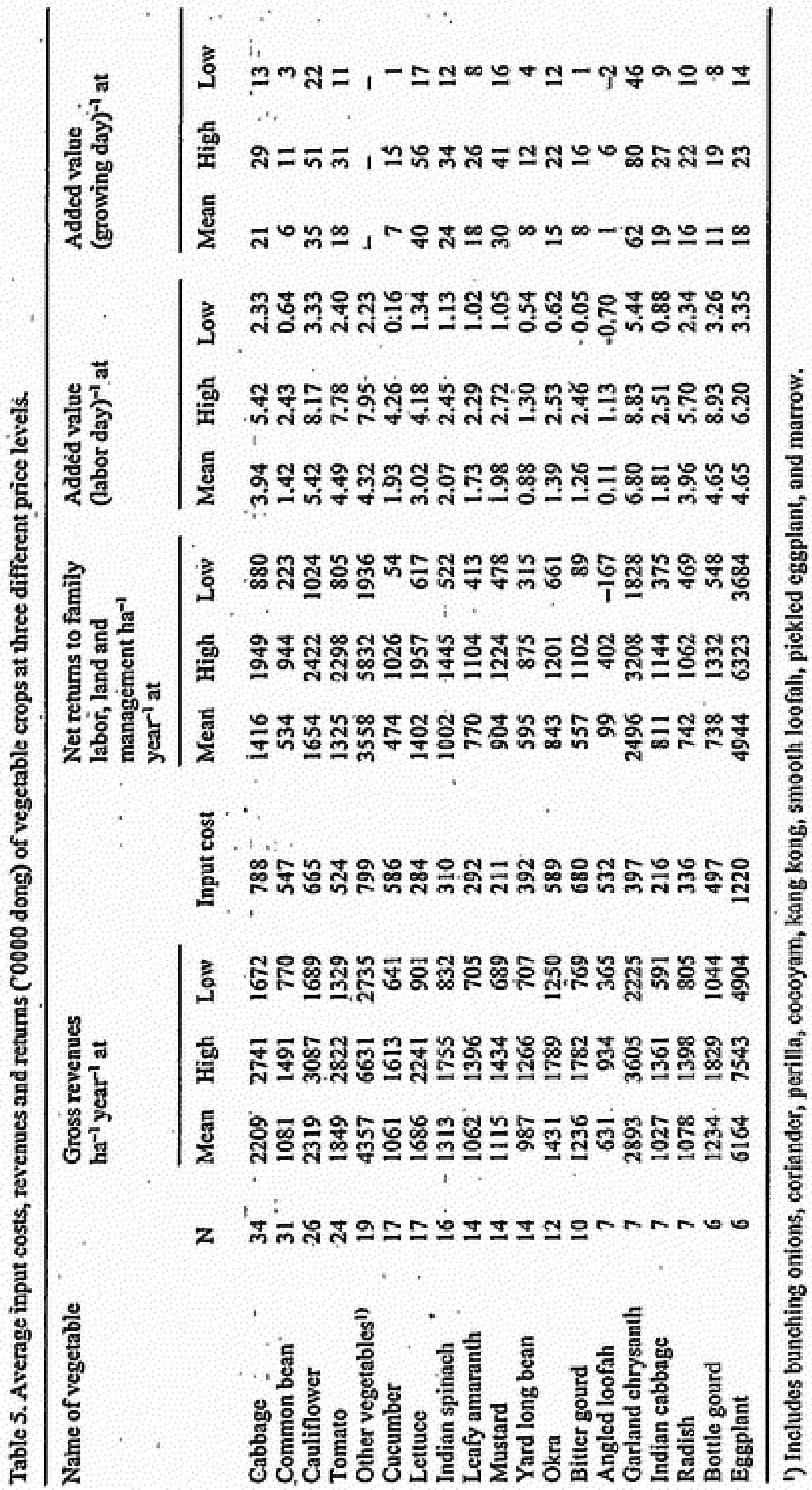


their production system, and those that do not, suggests that the latter achieve markedly higher yields for the majority of their crops. Animal waste and compost are more liberally applied to their vegetable crops by non-rice growers, as are inorganic fertilizers. As a result, input costs excluding family labor tend to be higher on non-rice farms, but so are net incomes (Jansen et al., 1995).

\section{Farm income per year}

Table 6 summarizes the results for revenues, costs and income farm ${ }^{-1}$ year $^{-1}$. Costs of irrigation pumps need to be spread over several years and were annualized using the following formula: $A=P\left[r /\left(1-(1+r)^{-1}\right)\right]$ where $A$ is the annualized capital cost of the pump; $\mathrm{P}$ is the current cost of the pump; $t$ is the assumed lifespan of the pump (3-20 years depending on pump type); and $\mathrm{r}$ is the discount rate (set at $10 \%$ ). Insufficient information was available to include the costs of wells and canals.

On the average, sample farmers derive over $70 \%$ of their crop revenues from the sale of vegetables (Table 6). Organic materials account for nearly half of the total input costs for vegetables, with chemical fertilizer and pesticides responsible for $80 \%$ of the remainder. Over $80 \%$ of total household income is derived from agriculture. Annual vegetable sales by farmers who do not produce rice reached 13.35 million dong $(\$ 1,250)$, compared to 9.68 million dong $(\$ 900)$ for farmers also cultivating rice. However, analysis in Jansen et al. (1995) reveals that, while overall income from agriculture was higher on farms without rice (\$750 vs. \$675), total household income was less ( $\$ 820$ vs. $\$ 840$ ). Expressed on $\mathrm{a} \mathrm{ha}^{-1} \mathrm{year}^{-1}$ basis, and grouped according to type of farm (i.e., vegetables alone, with rice, with rice and non-rice crops, or with non-rice crops), total household income was highest for the latter. Offfarm income was also higher for this farm type, but variation in household income was the least for this farm type, followed by the vegetable alone system. The cultivation of high-value flowers by the non-rice crop growers is responsible for their particularly high income.

\section{Agronomic practices}

Intercropping is not done, mainly because of already high planting densities. However, certain crop rotations (most revolving around a rice-vegetable rotation, often with a leafy vegetable following rice) are deliberately practiced. Main uses of crop residues include composting, direct incorporation, burning and, alternatively, animal feed. Expense (rice straw is often used as cattle feed and can reach a peak price of $\$ 20 \mathrm{~m}^{-3}$ ) and high labor requirements largely preclude mulching which is done by only one-fifth of all sample farmers. Weeding in vegetables is exclusively done by hand, sometimes as often as every one-and-one-half or two days. The average number of weedings is highest for leafy vegetables (on average between 4 and 9 times, i.c., 2 to 3 times more often than for most other vegetables), even though they are of shorter season duration (Jansen et al., 1995). Farmers tend to water all their vegetable crops daily by hand using electric pumps, plastic pipes and spray nozzles. Leafy vegetables may be watered twice daily but cole crops generally receive one 
Table 6. Revenues, costs and income per farm ('0000 Dong year-1, $N=98$ )

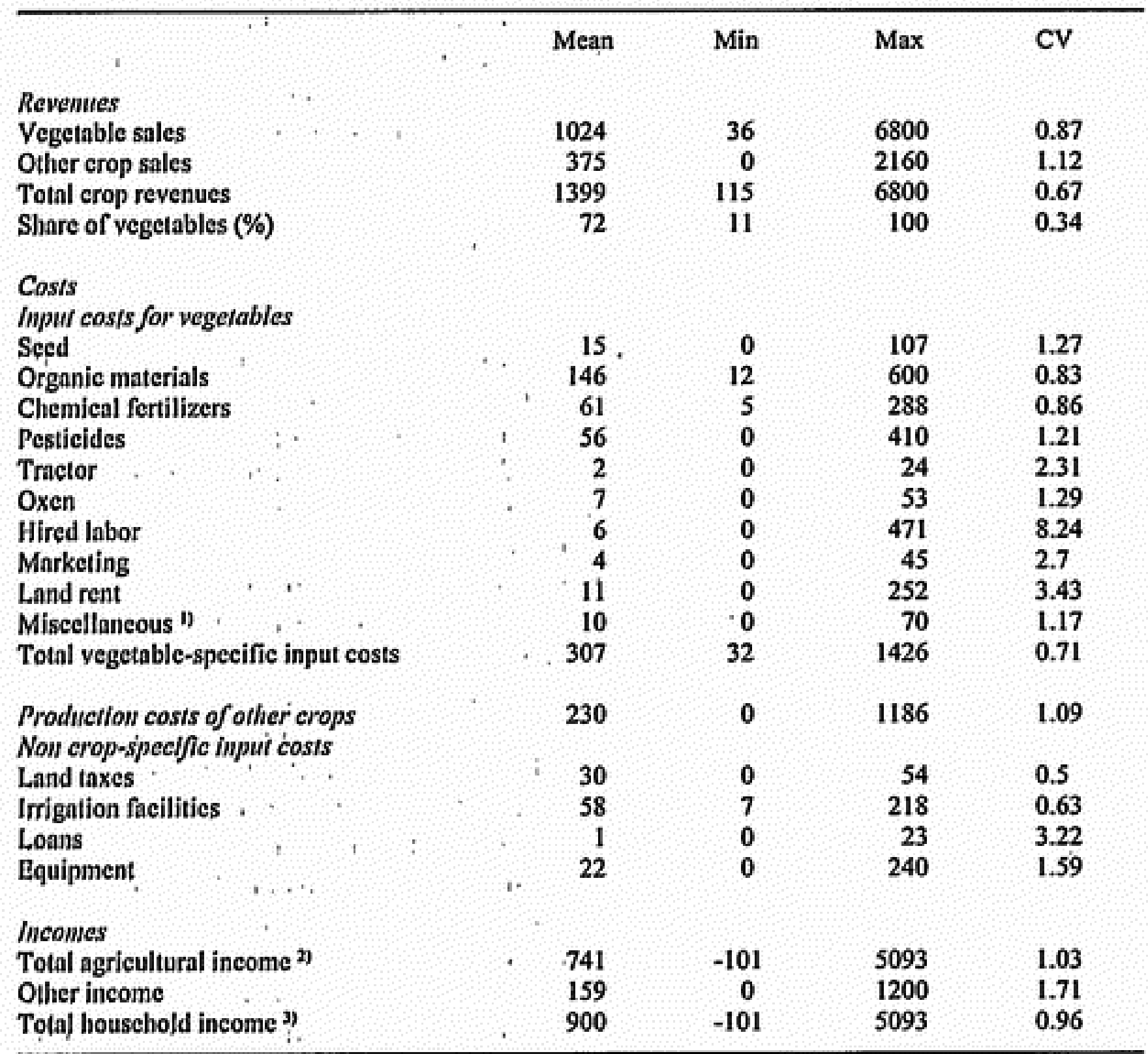

') Includes lime costs and any other costs not included elsewhere, e.g., land rent.

$\left.{ }^{2}\right)$ Defined as follows: total crop revenues + land rent received - total vegetable input costs for vegetables - input cost for other crops - non crop-specific input costs - land rent paid.

') Defined as follows; total agricultural income + any other income.

daily application. Land preparation is also largely done by hand; whereas tractors are not widely used (only 11 farmers), oxen were used by one-quarter of all sample farmers.

\section{Marketing}

Own consumption is negligible, and practically the entire vegetable production is sold, mostly to private traders who come to the farms. Traders may sell to middlemen in wholesale markets in HCMC or directly to other traders in retail markets located in both the city center and in peri-urban areas. Together with other farmers and farmers' cooperatives, private traders are the most important sources of marketing 
information for farmers. Public sources such as newspapers, radio and television hardly play a role in providing market information. As a result, farmers' marketing expenses are minor. Retail prices in one HCMC retail outlet in March 1994, at a time when vegetables are presumably in plentiful supply, showed considerable mark-up in price compared to the 1993 farm gate prices, suggesting farmers' shares of consumers' prices of typically around $20 \%$ only (Table 7 ).

\section{Farmers' constraints in peri-urban vegetable production}

Low and variable vegetable prices, and pest-related problems, were the most frequently mentioned constraints. Regarding the former, $70 \%$ of all respondent farmers has trouble with operating under what for most of them is a new phenomenon, i.e, operating under market conditions with their relatively large degree of uncertainty and corresponding variation in daily and seasonal prices, instead of more or less fixed prices set by the government $a_{\text {-priori }}$. Pests are considered a much more important yield-reducer than diseases (dominated by watery soft rot of crucifers and wilt of Solanaceous crops) on vegetables in southern Vietnam, despite the liberal use of insecticides. This may be partly due to the better availability of diseaseresistant as compared to pest-resistant varieties. Two thirds of farmers cited diamondback moth (DBM, Plutela xylostella) as their most common insect pest. Insect and disease control can account for up to $50 \%$ of total production costs in cabbage (Jansen et al., 1995; Nguyen, 1993). Approximately one half of all farmers use IPM (in the widest sense, i.e., to include rotations and manipulation of planting dates) but nearly two-thirds sense that their use of pesticide has increased compared to past usage. This has been coupled with a change in the spectrum of pesticides, indicative of induced pest tolerance. For DBM, farmers apply 20-30 times on each cabbage crop, with a mixture of at least two chemicals applied even if DBM is not present (Nguyen, 1993). Recommendations by the Institute of Agricultural Science to intercrop tomato and cabbage are being followed by some farmers, and with the objective use of Bt bio-insecticides an upsurge in natural enemies (e.g., Lycosa sp. of spider) has been documented even in areas where surrounding farmers continue their spray routines.

Table 7. Comparison between farm gate (high, low, average for 1992/3) and retail prices in Cho Ben Thanh retail market for March 1994 (in Dong $\mathrm{g}^{-1}$ ).

\begin{tabular}{llllll}
\hline Vegetable & \multicolumn{2}{l}{ Farm gate } & & Retail \\
\cline { 2 - 4 } & High & Low & Average & \\
nabbage & 921 & 556 & 736 & \\
Tomato & 1527 & 706 & 1013 & 2500 \\
Cutcumber & 1006 & 466 & 703 & 5000 \\
Eggplant & 767 & 408 & 567 & 4000 \\
Cauliflower & 1833 & 996 & 1354 & 3000 \\
Bilter gourd & 1830 & 820 & 1295 & 5000 \\
Okra & 967 & 554 & 692 & 4000 \\
\hline
\end{tabular}




\section{Environmental consequences of peri-urban vegetable production}

To date no monitoring of the probable build up of mineral nutrients and pesticides within the soil and ground water has been undertaken in vegetable growing areas in Vietnam. The high usage and low uptake of $\mathrm{N}$ on an annual basis should be cause for concern based upon monitoring studies elsewhere (Anonymous, 1995b), as should the accumulation of heavy metals from polluted sources of city compost (Drescher, 1994). Pesticide residues, both in harvested produce and that remaining in the edaphic environment, should also merit serious attention, for the annual rates of pesticide application in vegetables currently exceed those of many other food production systems (Midmore et al., 1996). The commonplace littering with plastic and other non-decomposable items of otherwise well-kept fields will increase if efforts to filter composts at the source are not undertaken. Besides being unsightly and a potential health hazard, plastic remains in the field may hinder precision field operations, especially sowing.

The use of water for irrigation of vegetables does not (yet) seem to seriously compete with domestic water use, but as more land is covered by buildings and roads there is less opportunity for recharge of subsurface water reserves, reducing water supply. A land sales tax constituted in 1992 has somewhat stemmed the speculation in land, which otherwise potentially led to inefficient land use for agriculture. A well-planned and implemented land use system will enhance the environmental friendliness of peri-urban vegetable production, if tied in with objective crop management techniques.

\section{Conclusions and implications for research policy}

With a total population of approximately 4.4 million, HCMC requires a vegetable supply of on the average $880 \mathrm{t} \mathrm{day}^{-1}$ if the minimum requirement of $200 \mathrm{~g} \mathrm{day}^{-1}$ capi$\mathrm{ta}^{-1}$ is to be satisfied. The Saigon Fruit and Vegetable Company, the major vegetable marketing agency in HCMC, estimates an average vegetable supply of $500 \mathrm{tday}^{-1}$, ranging from $300 \mathrm{t}^{\text {day }}{ }^{-1}$ in the lean wet season to $700 \mathrm{t}^{\text {day }}{ }^{-1}$ during the dry season. Market demand during the dry season is reputedly saturated while during the rainy season it is largely bolstered by supply from outside of HCMC. While leafy vegetables, due to their perishable nature, must be produced close to market for rapid retail, most other vegetables are more resilient to transport. Leafy vegetables are predominantly produced in Go Vap and Binh Chanh (respectively 5 and $15 \mathrm{~km}$ from the city center), with cauliflower, cabbage, radish and cucurbits being produced more distant from the center. Approximately $70 \%$ of vegetable produce from HCMC enters the city via the Hoc Mon district wholesale market. Vegetables from other areas, e.g., Dalat, Tien Giang Province and Long An Province enter HCMC via wholesale markets and largely comprise cabbage, shallots/onions, water melon, gourds and cucumber. Even though seasonality of supply from these zones was not studied, information obtained from market officials revealed that not more than 12 trucks each with 8 $t$ vegetable are sent daily to Can Muoa wholesale Market in HCMC and a similar 
number to the Chinese Market of HCMC. At Chinese new year, falling during the dry season, this number can reach 100 trucks day ${ }^{-1}$. On an annual basis, approximately $75 \%$ of vegetables consumed in HCMC is produced in the peri-urban 'Green Belt'. The proportion decreases during the hot and wet summer months.

Regarding the future, while favorable if judged by the demand and facility with which supply may be met in a peri-urban context, serious detractions with respect to the long-term sustainability and short-term public health and consumer credibility exist, Scope exists to improve upon the efficiency of input use, based upon a sound understanding of nutrient and water demand and supply, and an understanding of redueed dependence on pesticides as alternatives (e.g., biological control). Extensive monitoring of ground water for nitrates and pesticides is immediately necessary to establish causal relationships between 'hot spots' and vegetable farmers' production practices. The influence of improved production practices on pollutants must also be monitored.

Given the shortfall in vegetable supply during the late summer, the technical and economic feasibility (the latter compared to the relatively distant highland production areas) of summer peri-urban vegetable production should be investigated. An analysis of short-term economic gains versus long-term environmental consequences (including externality effects) should be undertaken for both peri-urban and highland vegetable production systems supplying HCMC.

\section{References}

Ali, M. \& S. Tsou, 1996. Combating micro-nutrient deficiency through vegetables: a neglected food frontier in Asia. Food Policy: forthcoming.

Anonymous, 1991. Development co-operation. Vietnam 1990 report. United Nations Development Program, Hanoi, $136 \mathrm{pp}$.

Anonymous, 1989, Victnam: agricultural and food production sector review. Draft Mission Report DD: DP/VIE/88/03 of UNDP, FAO and World Bank. UNDP, Hanoi, 81 pp.

Anonymous, 1994. World development report 1994. Oxford University Press, New York, 264 pp.

Anonymous, 1995a. Vietnam: the call of the city. The Economist, 4 March, p. 30.

Anonymous, 1995b. 1994 Progress report. Asian Vegetable Research and Development Center, Shanhua, $520 \mathrm{pp}$.

Barker, R., 1993. Investment priorities for sustaining agricultural growth and rural development in Vieınam. FAO Vietnam Mission (TCP/VIE/2252) Report. Food and Agriculture Organization of the United Nations, Rome, $47 \mathrm{pp}$.

Bottema, J.W.T, P.T. Binh, D.T. Ha, M.T. Hoanh \& H. Kim, 1991. Sweet potato in Vietnam, production and markets. Report No. 24. Regional Coordination Center for Research and Development of Coarse Grains, Pulses, Roots and Tuber Crops in the Humid Tropics of Asia and the Pacific (CGPRT Center), Bogor, $113 \mathrm{pp}$.

Drescher, A, 1994. Gardening on garbage: opportunity or threat? ILEIA Newsletter 10(4): 20-21.

Hayami, Y., 1993. Strategies for the reform of land property relations in Vietnam. FAO Vietnam Mission (TCP/VIE/2252) Report. Food and Agriculture Organization of the United Nations, Rome, 32 pp.

Hayami, Y, T. Kawagoe, S. Yokoyama, A.S. Bagyo \& A.K. Zakaria, 1990. Marketing innovations for vegetables: conditions of diversification in upland farming. Regional Coordination Center for Research and Development of Coarse Grains, Pulses, Roots and Tuber Crops in the Humid Tropies of Asia and the Pacific (CGPRT Center), Bogor, 87 pp. 


\section{PERI-URBAN VEGETABLE PRODUCTION SYSTEMS IN VIETNAM}

Jansen, H.G.P., 1992. Supply and demand of AVRDC mandate crops in Asia: implications of past trends for future development. Working Paper No. 4 (revised version). Asian Vegetable Research and Development Center, Shanhua, 85 pp.

Jansen, H.G.P., P.T. Binh, D.J. Midmore, S. Valasayya \& L.C. Tru, 1995. Peri-urban vegetable production in Ho Chi Minh City, Vietnam. Working Paper No. 11. Asian Vegetable Research and Development Center, Shanhua, 65 pp.

Khiem, N.T. \& T.D. Tien, 1996. Vegetable economics in Vietnam. In: Ali, M. \& H.G.P. Jansen (Eds.) Agricultural economics research on vegetable production and consumption patterns in Asia. Asian Vegetable Research and Development Center, Shanhua, Taiwan (fortheoming).

Midmore, D.J., H.G.P. Jansen, R.G. Dumsday \& S. Valasayya, 1996. Soil erosion and environmental impact of vegetable production in the Cameron Highlands, Malaysia. Agriculture, Ecosystems and Environment: fortheoming.

Nguyen, Q.H., 1993. Vegetable production and the damage of the Diamond Back Moth on cabbage in peri-urban areas of Ho Chi Minh City. Mimeograph, Institute of Science for Agriculture, Ho Chi Minh City, $16 \mathrm{pp}$.

Pingali, P,L. \& V.T, Xuan, 1992. Victnam: decollectivization and rice productivity growth. Economic Development and Cultural Change 40: 697-718.

Raunet, M., 1994. Esquisse des grandes paysages agricoles du Vietnam meridional. Agriculture et Développement 1: 29-38.

Timmer, C. P., 1992. Price policy for agricultural products and inputs: Asian experience and issues for Vietnam, HIID Development Discussion Paper no. 425 AFP. Harvard Institute for International Development, Cambridge, 55 pp.

Wiens, T.B., 1981. The economics of municipal vegetable supply in China. In: D.L. Plucknett \& H.K. Beemer, Jr. (Eds.) Vegetable farming systems in China. Westview Press, Colorado, pp. 281-322.

Xuan, V.T. \& C.P. Timmer, C. P., 1990. A food policy for Vietnam. HIID Development Discussion Paper no, 351, Harvard Institute for International Development, Cambridge, 58 pp. 